\title{
ECHINOCOCCOSIS IN SOUTHERN BRAZIL: EFFORTS TOWARD IMPLEMENTATION OF A CONTROL PROGRAM IN SANTANA DO LIVRAMENTO, RIO GRANDE DO SUL
}

\author{
Leila Neves FARIAS(1), Ramiro MALgOR(2), Cecília CASSARAVILlA(2), Caio BRAGANÇA(3) \& Mário Luiz DE LA RUE(1)
}

\begin{abstract}
SUMMARY
This investigation aimed to design a strategy for echinococcosis control in Santana do Livramento county, an endemic area in state of Rio Grande do Sul (Brazil). Fecal samples from 65 dogs were obtained from urban, suburban and rural areas. Purging with Arecoline Bromhidrate (AB) was done to visualize Echinococcus granulosus, and Enzyme Linked Immunosorbent Assay (ELISA) was performed to detect parasite coproantigen. Samples were obtained at the beginning and at the end of treatment with Praziquantel. A third fecal sampling was also done in rural areas four months after the end of treatment. Each dog was treated immediately after the first purging and every 30 days for eight months. In urban and suburban areas no infected dogs were found. In rural areas, first evaluation showed $11.36 \%$ and $27.69 \%$ of infected dogs by $\mathrm{AB}$ and ELISA, respectively. No infected dogs were diagnosed in the second evaluation and in the third evaluation $36.84 \%$ and $47.37 \%$ infected dogs were identified by AB and ELISA, respectively. Medication program to combat dog infection resulted in successful interruption of parasite transmission, but the project failed to create awareness of the need for dog prophylaxis among rural populations as well as to establish a permanent control program in this municipality.
\end{abstract}

KEYWORDS: Echinococcus granulosus; Control program; Rio Grande do Sul.

\section{INTRODUCTION}

Echinococcosis is a common parasitic disease in the state of Rio Grande do Sul (Brazil), and dogs are the major definitive hosts. The larval form and hydatid cysts are basically found in $25 \%$ of cattle and $3 \%$ of sheep, but human beings can be accidental hosts (716 cases between 1981-1999 in Rio Grande do Sul) $)^{5,10,19}$. It is caused by the tapeworm Echinococcus granulosus, which has long been recognized as an assembly of various distinct strains and, recently, species ${ }^{21}$. Despite its major rural distribution, urban areas may also harbor this cestode ${ }^{7}$. Control programs are widespread in endemic areas and based on strategies that interrupt the parasite's lifecycle and have a successful result in many countries. These programs are based on: (a) purging dogs with Arecoline Hydrobromide (AB), which besides its reasonable effect on cestode expulsion is also an aid to educating dog owners, since it is possible to actually show the parasite; and (b) dosing, frequently with praziquantel ${ }^{8,14}$. Both approaches have to be taken with some care, because these treatments have no ovicidal properties and eggs may contaminate the environment ${ }^{20}$. An example of a successful control program is the Uruguayan model, in which dogs are treated 12 times a year with praziquantel by staff members of the program and $\mathrm{AB}$ control is done at random 6 . In addition, owners receive continuous information about echinococcosis in humans and related problems ${ }^{6}$.

Santana do Livramento is an endemic region for Echinococcus in Rio Grande do Sul state and the area is on the border with Uruguay.
There is official legislation for Echinococcus control in this community, but unfortunately without effective implementation.

Based on the above situation, the aim of the present study was to carry out an Echinococcus survey in dogs, dosing each individual every month and motivate the beginning of a county commission for echinococcosis control in terms of prevention, education and prophylaxis knowledge in Santana do Livramento county.

\section{MATERIAL AND METHODS}

Visits were done on a regular basis from April 2001 to November 2002 in randomly chosen rural properties (farms), a suburban settlement with 400 inhabitants and urban areas/periphery of Santana do Livramento county. All properties were visited once a month for eight months and once again four months after the last praziquantel treatment.

The first evaluation/purging was done on 65 dogs (44 in rural, 11 in suburban and 10 in urban areas). The second was done one month after last treatment in 61 dogs (40 in rural, 11 in suburban and 10 in urban areas). Due to the high number of infected dogs, a third visit was done only in the rural area but only 19 dogs were found four months after the last treatment.

During the first visit, owners were asked about the number of dogs they kept, any kind of parasitological treatment, food sources, and how

1) Depto. de Microbiologia e Parasitologia, Univ. Federal de Santa Maria, RS, Brazil.

2) Unid. Biologia Parasitária. Instituto de Higiene, Montevideo, Uruguay.

3) Vigilância Sanitária, Santana do Livramento, RS, Brazil

Correspondence to: Mário Luiz de la Rue, Depto. de Microbiologia e Parasitologia/UFSM, 97105-900 Santa Maria, RS, Brazil. E-mail: delarue@ccs.ufsm.br 


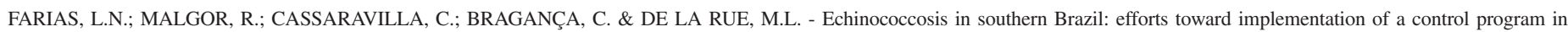
Santana do Livramento, Rio Grande do Sul. Rev. Inst. Med. trop. S. Paulo, 46(3):153-156, 2004.

they slaughter cattle and sheep at home. An informative explanation about epidemiology, transmission and pathological effects of hydatid disease in man was also done at the time of the first visit and in the following visits.

At the first visit, dogs were purged with Arecoline Bromhydrate (AB) (Sigma-Aldrich, St. Louis, USA) to observe the presence or absence of the parasite. The drug was administered orally in a $1.5 \%$ dilution (15 $\mathrm{mg}$ of $\mathrm{AB} / \mathrm{ml}$ distilled water), each dog receiving $3 \mathrm{mg} / \mathrm{kg}$, which is equivalent to $1 \mathrm{ml} / 5 \mathrm{~kg}$. Drug action began after 20 or 30 minutes. If the first purging failed, a second dose with half of the original concentration was done. Fecal samples were collected from adults (males and females). Parasite presence was observed in mucous feces, directly over a dark plate, diluting the material with water and formalin $(\mathrm{v} / \mathrm{v})^{11,17}$. Feces were also diluted $\left(2 \mathrm{~g} / 8 \mathrm{ml}\right.$ of $1 \%$ formalin solution) and stored at $-80{ }^{\circ} \mathrm{C}$ for coproantigen diagnosis.

Each dog was treated with praziquantel regardless of their diagnostic results (Droncitß-Bayer, S. Paulo, Brazil) $(5 \mathrm{mg} / \mathrm{kg})$ after first purgation and every 30 days until the $8^{\text {th }}$ month.

For coproantigen diagnostic, an ELISA was performed in the Parasitic Biology Laboratory of the Hygiene Institute (MontevideoUruguay) as previously described ${ }^{9}$. The cut-off value was determined by calculating the mean optical density (OD) at $492 \mathrm{~nm}+3$ standard deviations.

County public authorities and veterinarians accepted their responsibility to create a local commission for echinococcosis control during the field work until the end of dogs treatment (about eight months). This commission was responsible for registering the canine population, distributing praziquantel for each animal and developing prophylaxis methods for humans and dogs.

The different diagnostic procedures were compared by Chi-Squared test using the software "Statistical Analysis System" (SAS, 1993) ${ }^{16}$. The minimum significance level was $95 \%(\mathrm{p}<0.05)$.

\section{RESULTS AND DISCUSSION}

Questionnaire results are shown in Table 1. The custom among rural people of giving raw viscera, usually offal, to dogs was practiced in 26/ $44(58.3 \%)$ farms visited in the rural area, but it was not reported in suburban and urban areas. This situation was frequent because there were no separate facilities for the slaughtering of cattle and sheep and dogs are allowed to wander around during the slaughtering. Such practice was reported by a neighboring municipality in early 1991, and is common on rural properties and considered to be harmless by the farmers ${ }^{15}$. Feeding dogs with raw viscera has been reported as a cultural behavior ${ }^{1}$ and despite some efforts by educational programs done in the state of Rio Grande do Sul, the above situation has changed very little. As observed in the present work, people living on farms prefer to provide their dogs offal from the slaughtering instead of feeding them with another kind of food because they consider this procedure to be cheaper, more practical and easier.

Domiciliary slaughter occurs in $83.34 \%$ of rural properties in the open air (Table 1), but is not a common practice in urban and suburban
Table 1

Percentage of urban, suburban and rural properties, where dogs received antihelminthic treatment, ate raw viscera and that have open slaughtering facilities in Santana do Livramento county, RS, Brazil

\begin{tabular}{lccc}
\hline Questions & \multicolumn{3}{c}{ Type of property visited } \\
\cline { 2 - 4 } & Rural & Suburban & Urban \\
\cline { 2 - 4 } & & $\%$ \\
\hline Anti-helminthic treatment & $61.90^{\mathrm{a}}$ & $10.11^{\mathrm{b}}$ & $77.78^{\mathrm{a}}$ \\
Raw viscera eating & $58.33^{\mathrm{a}}$ & $0.00^{\mathrm{b}}$ & $0.00^{\mathrm{a}}$ \\
Open slaughtering facilities & 83.34 & - & - \\
\hline
\end{tabular}

Values with different letters in the same row are significantly different $(\mathrm{p}<0.05)$

areas. It was also observed ${ }^{15}$ that almost all rural properties in Uruguaiana, another county in the state of Rio Grande do Sul, make use of this system to obtain meat. In general, dogs are present and waiting to eat the viscera.

In urban and rural areas there was a higher number of dog owners that provided their dogs with some kind of antihelminthic treatment (61.90\% and $77.78 \%$, respectively) than in the sub-urban region $(10.00 \%)$ $(\mathrm{p}<0.05)$ (Table 1). A socioeconomic investigation was not performed, but during visits it could be observed that in suburban regions, people were less knowledgeable about zoonosis than people from other areas, which impairs any initiative for antihelminthic treatment. Dogs owners who reportedly treated their farm animals on a regular basis usually used benzimidazole, because it seemed practical for them to use the same drug for both dogs and sheep. Both therapeutic and prophylactic Echinococcus treatment for dogs were preferentially done with praziquantel, which is $100 \%$ effective against the adult form in all treated dogs but without ovicidal properties ${ }^{4,20}$. In an epidemiological investigation in Uruguaiana ${ }^{15}$ it was verified that only $11.5 \%$ of the rural properties used praziquantel and that this was applied on an irregular basis, and $36.50 \%$ reported that they used the same product as for their sheep. Lack of information and misunderstanding regarding the antihelminthic effect of drugs were very common. It was not intended to analyze the reasons for this phenomenon, but the fact must be taken into account to improve the effectiveness of any kind of program to control E. granulosus. A person living in an endemic area has to be instructed about the importance of correct treatment and its impact on hindering transmission to an intermediate host.

In urban areas, there were no dogs infected with E. granulosus. This result was expected because contact with raw viscera is infrequent in urban properties and in the suburban area infection levels were surprising low; only one dog had a positive coproantigen test for E. granulosus, despite the fact that dogs have contact with farms in the neighborhood and wander unrestrained around their home area. It has been previously reported ${ }^{7}$ that stray dogs from urban areas of small cities can be infected with this parasite, but possibly due to the small number of suburban dogs analyzed (11) the presence of the parasite was not found. Nevertheless, conditions that favor transmission continue to be present ${ }^{5}$ and infection could occur.

On the other hand, rural areas presented a different situation. Detection of the parasite by coproantigen (ELISA) showed better results than analysis by AB purging (Table 2$)(\mathrm{p}<0.05)$. Several studies 


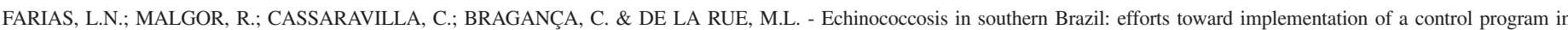
Santana do Livramento, Rio Grande do Sul. Rev. Inst. Med. trop. S. Paulo, 46(3):153-156, 2004.

comparing Coproantigen ELISA and Arecoline Bromhidrate purging recommend the use of the former rather than the latter ${ }^{2,13,18,22}$. The diagnostic techniques utilized in the present work have various controversial problems. Firstly is the purging efficacy, since only $70 \%$ of dogs react to $\mathrm{AB}$ after the first dose and its action may be increased to $78 \%$ after a second dose ${ }^{18}$, however it is $100 \%$ specific and the parasite is visualized directly ${ }^{22}$. Cross-reaction between E. granulosus and Taenia hydatigena may occur in coproantigen diagnostic ${ }^{3}$ and in the first visit T. hydatigena was found in three samples, but ELISA was negative for E. granulosus, thereby avoiding conflicting results. However, both techniques were used in the present work for complementary results. Despite the low efficacy of $\mathrm{AB}$ technique, it has the advantage that through the purging mechanism the parasite remains intact and can be shown to rural people so it has an educational effect ${ }^{17}$, while ELISA is more appropriate for laboratory or research purposes ${ }^{2}$.

Table 2

Presence of Echinococcus granulosus infected dogs, analyzed by Arecoline Bromhidrate $(\mathrm{AB})$ purging and Coproantigen (ELISA technique) in the rural zone of Santana do Livramento County, RS, Brazil

\begin{tabular}{lccc}
\hline Technique & $1^{\text {st }}$ evaluation & $2^{\text {nd }}$ evaluation & $3^{\text {rd }}$ evaluation \\
\cline { 2 - 4 } & \multicolumn{3}{c}{$\%$ positive } \\
\hline Purging & $7.69(5 / 44)^{\mathrm{a}}$ & $0.00(0 / 40)$ & $36.84(7 / 19)^{\mathrm{ab}}$ \\
Coproantigen & $27.69(17 / 44)^{\mathrm{b}}$ & $0.00(0 / 40)$ & $47.37(9 / 19)^{\mathrm{ab}}$ \\
\hline
\end{tabular}

Values with different letters in the same column are significantly different $(\mathrm{p}<$ 0.05 ); Values with different letters in the same row are significantly different $(\mathrm{p}<0.05)$

As expected, 30 days after the last treatment with praziquantel, no infected dogs were found in all studied areas (Table 2). Similarly, dog infection evaluation was performed in Uruguay (1997) to investigate the efficiency of an echinococcosis control program which began in 1992. Infection rates decreased from $10.67 \%$ in 1992 to $0.74 \%$ in 1997 , showing that a program based on praziquantel treatment every 30 days is a powerful tool for echinococcosis control ${ }^{12}$. In the present control program, the results undoubtedly lead to the same conclusion and demonstrated that a simple method can provide good results.

Four months after the last treatment, a third evaluation was done in the rural area. Dogs were purged again and samples for coproantigen diagnostic collected (Table 2). Only 32/44 dogs seen in the first visit were found. No feces were collected from four dogs and no mucous samples were obtained in nine dogs, which hindered the possibility of visualizing E. granulosus. The increase in dog infection rate $(\mathrm{p}<0.05)$ obtained in the third evaluation, when compared with the first revealed an important epidemiological problem regarding the control of this zoonosis. It was difficult to establish the reason why people in the rural area failed to take enough care to prevent dogs from having contact with raw viscera after the preventive program ended. It seems that it is a common misconception among them that this treatment is a form of vaccine and as such dogs are immunized against the parasite and thus cannot be re-infected. Therefore, it is important to underscore that any kind of control program must begin with an educational campaign to overcome these people's resistance to changing their habits.

Another objective of this work was to create a Local Commission
Against Hydatidosis in Santana do Livramento county to implement a control program. Unfortunately, local authorities, veterinarians and Public Health authorities did not continue this project after its end and probably the situation will continue unchanged.

There is no geographical barrier between Santana do Livramento (Brazil) and Rivera (Uruguay), a city in which the National Commission for Control of Hydatidosis promotes a control program to avoid echinococcosis/hydatidosis since $1990^{6}$. Consequently, for any kind of control program involving animals to be truly effective, it has to be done on both sides of the geographical/political limit because dogs can freely wander from one country to the other.

It was concluded that a control program with the objective of reducing the impact of echinococcosis in man or animals must be continuous, at least until information about its transmission are clear and fully understood by all the people involved.

\section{RESUMO}

\section{Equinococose no sul do Brasil: tentativas para implementação de um programa de controle em Santana do Livramento, Rio Grande do Sul}

Este trabalho objetivou implementar um programa de controle da equinococose no município de Santana do Livramento, área endêmica no Estado do Rio Grande do Sul (Brasil). Amostras fecais de 65 cães foram coletadas em áreas urbanas, suburbanas e rurais. Para visualizar o Echinococcus granulosus foi realizada purgação com Bromhidrato de Arecolina (BA) e para identificar coproantígenos parasitários foi empregado um método imunoenzimático (ELISA). As amostras foram coletadas no começo e ao fim do tratamento com Praziquantel. Nas áreas rurais uma terceira coleta foi feita quatro meses após o fim do tratamento. Cada cão foi tratado no começo e a cada trinta dias durante 8 meses. Nas áreas urbanas e suburbanas nenhum cão parasitado foi identificado. Nas áreas rurais estavam parasitados $11,36 \%$ e $27,69 \%$ dos cães, por BA e ELISA, respectivamente. Na terceira avaliação, 36,84\% e 47,37\% dos cães estavam infectados, por BA e ELISA, respectivamente. Observouse que um programa a base de drogas anti-parasitárias resultou em interrupção eficiente na transmissão parasitária, mas o projeto falhou em criar uma mentalidade consciente nos habitantes da zona rural relacionada a profilaxia, bem como em estabelecer um programa permanente de controle desta parasitose no município.

\section{ACKNOWLEDGEMENTS}

The authors wish to thank Bayer S.A. (São Paulo, Brazil) for kindly supplying Praziquantel (Droncit).

\section{REFERENCES}

1. ACHA, P.N. \& SZYFRES, B. - Hidatidosis. In: ACHA, P.N. \& SZYFRES, B. Zoonosis y enfermedades transmissibles comunes al hombre y a los animales. Parasitosis. 3. ed. Washington, OPS, 2003. p. 195-211.

2. CRAIG, P.S.; GASSER, R.B.; PARADA, L. et al. - Diagnosis of canine echinococcosis: comparison of coproantigen and serum antibody tests with arecoline purgation in Uruguay. Vet. Parasit., 56: 293-301, 1995. 


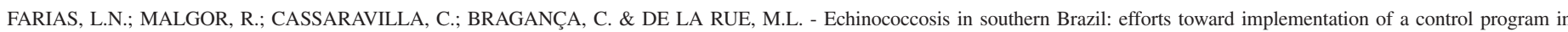
Santana do Livramento, Rio Grande do Sul. Rev. Inst. Med. trop. S. Paulo, 46(3):153-156, 2004.

3. DEPLAZES, P.; GOTTSTEIN, B.; ECKERT, J. et al. - Detection of Echinococcus coproantigens by enzyme-linked immunosorbent assay in dogs, dingoes and foxes. Parasit. Res., 78: 303-308, 1992.

4. ECKERT, J.; GEMMEL, M.; MATYAS, Z. \& SOULSBY, E.J.L. - Guidelines for surveillance, prevention and control of echinococcosis/hydatidosis. Geneva, World Health Organization, 1984.

5. ECKERT, J.; SCHANTZ, P.M.; GASSER, R.B. et al. - Geographic distribution and prevalence. In: ECKERT, J.; GEMMEL, M.; MESLIN, F-X. \& PAWLOWSKI, Z.S. WHO/OIE manual of echinococcosis in humans and animals: a public health problem of global concern. Paris, WHO/OIE, 2001. p. 100-142.

6. ECONOMIDES, P.; LARRIEU, E.J. \& ORLANDO, D. - Evolution of programmes for control of Echinococcus granulosus (examples). In: ECKERT, J.; GEMMEL, M.; MESLIN, F-X. \& PAWLOWSKI, Z.S. WHO/OIE manual of echinococcosis in humans and animals: a public health problem of global concern. Paris, WHO/ OIE, 2001. p. 204-209.

7. HOFFMANN, A.N.; MALGOR, R. \& DE LA RUE, M.L. - Prevalência de Echinococcus granulosus (Batsch, 1786) em cães urbanos errantes do município de D. Pedrito. Ciênc. rural, 31: 843-847, 2001

8. MACPHERSON, C.N.L.; ZEYHLE, E. \& ROMIG, T. - An Echinococcus pilot control programme for north-west Turkana, Kenya. Ann. trop. Med. Parasit., 78: 188-192, 1984.

9. MALGOR., R.; NONAKA, N.; BASMADJIAN, I. et al. - Coproantigen detection in dogs experimentally and naturally infected with Echinococcus granulosus by a monoclonal antibody-based enzyme-linked immunosorbent assay. Int. J. Parasit., 27: 1605-1612, 1997.

10. MARDINI, L.B.L.F. \& SOUZA, M.A.T. - Programa de controle da hidatidose humana no estado do Rio Grande do Sul, Brasil. Bol. Hidatid., 39-43, 1999.

11. OFFICE INTERNATIONAL DES EPIZOOTIES (OIE) - Echinococcosis/Hydatidosis. In: Manual of standards for diagnostic tests and vaccines. 3. ed.. Paris, Office International des Epizooties, 1996. p. 192-197.

12. ORLANDO, D.F. - Evolution of the programme for the control of hydatidosis in Uruguay. Arch. int. Hidatid., 32: 69-72, 1997.
13. RUYZ, A.; SCHANTZ, P. \& ARAMBULO III, P. - Proceedings of the Scientific Working Group on the advances in the prevention, control and treatment of hydatidosis. Montevideo, Pan American Health Organization, 1995.

14. SANTILLÁN, G. - Vigilancia de la contaminación ambiental por Echinococcus sp. Arch. int. Hidatid., 33: 11-13, 1999.

15. SANTOS, A.F.; SANTOS, H.T. \& MOREIRA, W.S. - Fatores epidemiológicos importantes na propagação da hidatidose em propriedades rurais no município de Uruguaiana, RS, Brasil. In: CONGRESO LATINOAMERICANO DE PARASITOLOGIA, 10, Montevideo, 1991. Resumenes. p. 456.

16. SAS Institute - SAS ${ }^{\circledR}$ User’s guide: statistics. Ver. 6.08. 4. ed. Cary, 1993.

17. SCHANTZ, P.M - Guía para el empleo del bromhidrato de arecolina en el diagnóstico de la infección por Echinococcus granulosus en el perro. Bol. chil. Parasit., 28: 81-90, 1973.

18. SCHANTZ, P.M - Sources and uses of surveillance data for cystic echinococcosis. In: ANDERSEN, F.L.; OUHELLI, H. \& KACHANI, M. Compendium on cystic echinococcosis in Africa and in Middle Eastern countries with special reference to Morocco. Provo, Brigham Young University, 1997. p. 72-84.

19. SIF (SERVIÇO DE INSPEÇÃO FEDERAL). Brazilian Agricultural Ministry, 2001. (Personal communication).

20. THAKUR, A.S.; PREZIOSO, U. \& MARCHEVSKY, N. - Efficacy of droncit against Echinococcus granulosus infection in dogs. Amer. J. vet. Res., 39: 859-860, 1978.

21. THOMPSON, R.C.A. \& McMANUS, D.P. - Towards a taxonomic revision of the genus Echinococcus. Trends Parasit., 18: 452-457, 2002.

22. WACHIRA, T.M.; MACPHERSON, C.N.L. \& GATHUMA, J.M. - Hydatic disease in the Turkana district of Kenya. VII. Analysis of the infection pressure between definitive and intermediate hosts of Echinococcus granulosus 1979-1988. Ann. trop. Med. Parasit., 84: 361-368, 1990.

Received: 25 November 2003

Accepted: 31 May 2004 